\title{
Fiscaoeconomia
}

E-ISSN: 2564-7504

2022, Volume 6, Issue 1, 118-141

https://dergipark.org.tr/tr/pub/fsecon

\section{Birincil Sektör Olarak Tarımın Dış Ticaretteki Stratejik Rolü}

\section{The Strategic Role of Agriculture as a Primary Sector in Foreign Trade}

\section{Merve EKici ${ }^{1}$, Filiz TUTAR ${ }^{2}$}

\section{Öz}

Tarımsal üretim geçmiş dönemlerde olduğu gibi bugün de faaliyetlerini sürdürmektedir. Artan nüfusun gıda ihtiyacını karşılamak, güvenilir gıdaya erişimi sağlamak ve verimli üretimin gerçekleştirilmesi tarım sektörünün birinci hedefini oluşturmaktadır. Fakat bu hedefin gerçekleştirilmesi için tarımsal girdi maliyetlerinin azaltılması gerekmektedir. Dolayısıyla Türkiye'nin bu konuda tarımsal politikalarını ve destekleme faaliyetlerini güncellemesi bir ön koşul niteliğindedir. Özellikle sanayi sektörüne kaynak girdi sağlaması tarımsal üretimi stratejik hale getirmektedir. Tarım sektörünün devlet tarafından birincil öneme sahip statüye yükseltilmesi ve tarımsal destekleme politikalarının iyileştirilmesi gerekmektedir.

Çalışmanın amacı tarım sektörünün dış ticaret açısından önemini vurgulamaktır. Bu doğrultuda sektöre ar-ge ve yatırım faaliyetlerinin kazandırılması; üretimde sürekliliği ve verimliliği sağlayarak dışa bağımlılık oranının azaltılmasına yardımcı olacaktır. Bu konuda üretimin ve çiftçilik mesleğinin özendirilmesine yönelik tarımsal politikalar geliştirilmelidir. Türkiye'nin tarım sektöründe ve tarımsal üretimin dış ticaretine yönelik sahip olduğu zayıf/güçlü ve fırsat/tehditler belirtilerek SWOT analizi uygulanmıştır. Analiz sonucunda tarım sektörünün geliştirilmesi gerektiği ve hammadde kaynağına sahip olmanın üretimde ve dış ticarette büyük bir üstünlük sağladığı sonucuna ulaşıımıştır.

Jel Kodları: Q14, Q17, Q18.

Anahtar Kelimeler: Tarım, Tarımsal Verimlilik, Tarım Politikaları, Dış Ticaret.

\footnotetext{
1 Doktora Öğrencisi, Niğde Ömer Halisdemir Üniversitesi, SBE İktisat ABD, merve ekici 71@hotmail.com, ORCID: 0000-0002-0974-3498

2 Doç. Dr., Niğde Ömer Halisdemir Üniversitesi, iiBF, iktisat Bölümü, flztutar@hotmail.com, ORCID: 0000-00022574-9494
}

Citation/Atıf: Ekici, M. \& Tutar, F. (2022). Birincil Sektör Olarak Tarımın Dış Ticaretteki Stratejik Rolü. Fiscaoeconomia, 6(1), 118-141. Doi: 10.25295/fsecon.991823 
Ekici, M. \& Tutar, F. (2022). Birincil Sektör Olarak Tarımın Dış Ticaretteki Stratejik Rolü.

Fiscaoeconomia, 6(1), 118-141. Doi: 10.25295/fsecon.991823

\begin{abstract}
Agricultural production continues its activities today as it was in the past. Meeting the food needs of the increasing population, providing access to safe food and achieving efficient production are the primary goals of the agricultural sector. However, in order to achieve this goal, agricultural input costs need to be reduced. Therefore, it is a prerequisite for Turkey to update its agricultural policies and support activities in this regard. In particular, providing resource input to the industrial sector makes agricultural production strategic. It is necessary to raise the agricultural sector to the status of primary importance by the state and to improve agricultural support policies.
\end{abstract}

Purpose of the study is emphasizing the importance of the agricultural sector in terms of foreign trade. In this direction, providing the sector with R\&D and investment activities; It will help reduce the foreign dependency ratio by providing continuity and efficiency in production. In this regard, agricultural policies should be developed to increase production and the encourage farming profession. SWOT analysis was applied by specifying the weak/strong and opportunities/threats that Turkey has in the agricultural sector and foreign trade of agricultural production. As a result of the analysis, it was concluded that the agricultural sector should be developed and having a raw material source provides a great advantage in production and foreign trade.

Jel Codes: Q14, Q17, Q18.

Keywords: Agriculture, Agricultural Productivity, Agricultural Policies, Foreign Trade.

\title{
1. Giriş
}

Tarım, insan yaşamını doğrudan etkileyebilme özelliğine sahip bir sektördür. Üretimin gerçekleştirilmesi ve insan neslinin devamının sağlanabilmesi tarım sektörünün elindedir. Bu denli önem arz eden sektörde geçmişten günümüze kadar üretim sürecinde, tarımsal politikalarda ve teknolojilerde bazı inovasyonlar yapılmıştır. Bu inovasyonlar arasında; kaliteli tohum, makineleşme, kurumsallaşma, kooperatifçilik ve sulama yer almaktadır. Ortaya çıkan bu inovatif gelişmeler tarımsal verimliliğin artırılmasına ve dış ticarette üstünlük sağlanmasına katkıda bulunmaktadır. Tarım ürünlerinin ihracatında öncelikli hedef katma değeri yüksek malların pazarlanmasıdır. Bu mallar ülkeye daha çok hasıla sağlamaktadır. Türkiye, tarımsal ürün ihracatında iyi bir potansiyele sahiptir. 1950 yılından önce tarıma dayalı bir ekonomisi olan Türkiye, 1950 yılından sonra sanayiye dayalı bir ekonomi anlayışını benimsemeye başlamıştır. Tarım ve sanayinin birlikte geliştirilmesi ülkenin sadece gıda ihtiyacının sağlanacağı anlamına gelmemektedir. Üretim fazlası malların pazarlanması ülkeye döviz girişini artıracak ve sanayiye hammadde temin edilmesini kolaylaştırarak hasılanın artmasına dolayısıyla da dış ticaretin gelişmesine katkıda bulunacaktır. 1980'li yıllardan itibaren dış ticarette serbestleşme politikasının benimsenmesi tarım sektörünü yakından ilgilendiren bir uygulama olmuştur. Bu politika kararından sonra dış ticarette dengenin sağlanması amacıyla tarımsal verimlilik kavramı önem kazanmıştır. Tarım politikalarına güncelleme getiren Türkiye; sulama alanlarını ve ürün çeşitliliğini artırmış, tarım arazilerini genişletmiş ve ulaşım koridorlarını iyileştirmiştir.

Türkiye'de tarım sektörünün gelişmesi ve tarımsal dış ticaretin artırılması için teşviklerin ve sulama olanaklarının artırıması, yönderlik (mentor) eğitiminin verilmesi, toprağın miras 
Ekici, M. \& Tutar, F. (2022). Birincil Sektör Olarak Tarımın Dış Ticaretteki Stratejik Rolü.

Fiscaoeconomia, 6(1), 118-141. Doi: 10.25295/fsecon.991823

nedeniyle parçalanmaması, sulama olanaklarının artırılması ve kaliteli tohum kullanımının yaygınlaştırılması gerekmektedir. Çünkü ülkenin üç tarafının denizlerle çevrili olması, toprağının ve ikliminin üretime elverişli olması; daha çok tarımsal üretim gerçekleştirilmesini ve ihracat oranlarının artırılmasını gerektirmektedir. Türkiye'de tarım sektörünün milli gelir ve istihdam içerisindeki payı azalmaktadır. Fakat tarımsal faaliyetlerin ekonomik etkilerinin dışında sosyal ve çevresel etkilerinin de bulunması sektörün ticari faaliyetlerdeki üstünlük durumunu belirtmektedir. Dolayısıyla tarımsal arz güvenliği, tarımsal fiyatların yüksekliği, tarımda verimin düşmesi, destekleme politikalarının yetersizliği, tarımda dışa bağımlıığın artması ve kendi kendine yeten ülke konumundan çıkılması sadece tarım sektörünü ilgilendiren bir konu değildir. Türkiye'nin sanayi, turizm, gıda, tekstil gibi birçok alanda tarım sektörünün etkisi görülmektedir.

Tarım sektörünün birincil sektör olma özelliği birçok araştırmalara konu olmuştur. Türkiye'nin dış ticaretinde tarımsal üretimin payına yönelik araştırmalar içerisinde; Yayer ve Karkacıer (2003), Aydın (2009), Uzundumlu (2012), Aydın ve Aydın (2018), Çetin (2020) tarafından yapılan çalışmalar yer almaktadır.

Yayer ve Karkacıer (2003), çalışmalarında Türkiye'nin tarım sektörü dış ticaretinin gelişimini incelemişlerdir. Box-Jenkins tahmin yöntemi kullanılarak 1985-2000 arasındaki dönemde ihracat ve ithalat trendleri tahmin edilmiştir. Gelecek yıllar içerisinde salt tarım ürünleri ihracatında bir azalma olacağı, salt tarım ürünleri ithalatının ise projeksiyonu yapılan dönemde uygulanan politikalarla sabit kalacağı sonucuna ulaşılmıştır.

Aydın (2009), çalışmasında ISIC Rev.3 sınıflamasını kullanarak Türkiye'nin tarım ve hayvancılıkta 2000 yılından önceki dönemlerde dış ticarette fazla verildiğini fakat 2000 yılından sonraki dönemlerde ise dış ticarette açıklığın başladığını ifade etmiştir. Tarımsal üretimin nüfus artış oranına göre geride kaldığı, gelecek dönemlerde küresel ısınma ve iklim değişimleri ile tarımsal üretimde aksaklıkların yaşanabileceğini vurgulamıştır.

Uzundumlu (2012), Türkiye'de tarım sektörünün son 15 yıllık değişimine değinerek, üreticilerin tüketici konumuna geldiğini belirtmiştir. Çalışmada; Türkiye tarım sektöründe kendi kendine yetecek ve tarıma dayalı sanayi mallarında $A B$ gibi gelişmiş ülkelerle rekabet edebilecek düzeyde ve kalitede tarımsal üretim gerçekleştirmeli sonucuna ulaşılmıştır.

Aydın ve Aydın (2018), çalışmalarında 2000 yılından önce dünyada en önemli ve en büyük ihracatçı ülke olma özelliği taşıyan Türkiye, artık bu konumunu kaybederek ithalatçı ülke sonucuna ulaşmıştır. 1980 yılının ortasından itibaren tarımsal hammadde dış ticaretinde bir açık oluşmaya başlamış ve bu açığın günümüze kadar devam ettiği vurgulanmıştır.

Çetin (2020), Türkiye'nin Standart Uluslararası Ticaret Sınıflaması (SITC)'na göre tarım ürünleri ticareti için üretilen 1990-2017 döneminin yıllık verileri kullanılmıştır. Çalışmada, tarım sektöründeki uluslararası gelişmeler kendi kendine yeterliliği doğrudan etkilemekte olup, 2000 'li yıllardan sonra tarım sektöründe dışa bağımlılığın arttığı sonucuna ulaşmıştır.

Bu çalışma, Türkiye'nin dış ticaretinde tarım sektörünün yerini ve payını incelemektedir. Çalışmanın çerçevesinde ilk olarak tarım sektörüne yönelik destekleme politikaları hakkında bilgi verilecektir. İkinci olarak, tarımsal verimlilik ve dış ticaret konusu ele alınacak, güncel rakamlarla bu konu desteklenecektir. Üçüncü olarak, tarımsal üretimde ve dış ticaretinde 
Ekici, M. \& Tutar, F. (2022). Birincil Sektör Olarak Tarımın Dış Ticaretteki Stratejik Rolü.

Fiscaoeconomia, 6(1), 118-141. Doi: 10.25295/fsecon.991823

Türkiye'nin sahip olduğu güçlü/zayıf ve fırsat/tehdit yönleri ele alınarak, bir SWOT analizi gerçekleştirilecektir.

\section{Tarımsal Destekleme Politikaları}

Tarım sektöründe üretim süreci uzun, verimlilik düşük, sermaye birikimi yetersiz, yatırımlar az ve parasal geri dönüşüm hızı düşük olan bir sektördür. Bu olumsuz faktörler tarımsal teşvik ve destekleme politikalarının önemini ortaya koymaktadır. Destekleme ve teşvik politikalarının üretici gelir seviyesinin iyileşmesini, gıda güvencesini sağlamasını, tüketicilere uygun fiyatlı ürün temin edilmesini, kırsal kalkınmayı, üretim ve verimlilik artışı gibi amaçları benimsemesi gerekmektedir (Aktaş, vd., 2015: 57).

Türkiye, tarımda yenileşmeye 2000'li yıllardan sonra başlamıştır. 2001 yılında yaşanan ekonomik kriz tüm dünyada farklı etkiler yaratmıştır. Bu etkinin tarım sektörü açısından Türkiye'ye yansıması yeni inovasyonların gerçekleştirilmesine zemin hazırlamıştır. Plânlı dönem öncesinde uygulanan tarımsal destekleme politikalarının yetersizliği, yerine ulaşamaması, var olan desteklerin bütçeye ağır gelmesi ve kalkınma hedeflerinin gerçekleştirilememesi gibi nedenlerden dolayı eleştirilmiştir. Bu bağlamda yeni bir politikanın tam anlamıyla hayata geçirilmesi gerekliliği gün yüzüne çıkmıştır. Bu 2002 yılında başlayan Tarım Reformu Uygulama Projesi'dir. Bu projedeki hedefler; farklı tarım ürünlerinde sadece kendi kendine yetebilecek kadar üretimi değil, karşılaştırmalı üstünlüğe sahip olunabilecek ürünlerin de yetiştirilmesini belirtmiş, doğrudan gelir desteği sistemi hayata geçirmiş ve ihracata yönelik bir büyüme hedefi anlayışını sektöre enjekte etmiştir (Taştanoğlu, 2018: 84).

Üreticilerin yaşam kalitesini artırmak, tüketicilere güvenilir, temiz, kaliteli ve ucuz gıda temin etmek amacıyla tarım politikaları ortaya çıkmıştır. Bu politikalar içerisinde; pazar fiyatı desteği, doğrudan gelir desteği, dolaylı gelir destekleri (ayrıcalıklı kredi, sigortalama, depolama, girdi sübvansiyonları), vergilendirme gibi uygulamalar söz konusudur. Tarım sektöründe politikaların temel taşı tarımsal destekleme alım-satım işlemlerinin uygulanmasıdır. Bu uygulama iç pazarda destekleyici, dış pazara karşı ise koruyucu niteliktedir. Türkiye'de plânlı kalkınma döneminden itibaren uygulanmaya başlayan ve devam eden tarımsal ürünlere sübvansiyon uygulamasında miktar ve bileşim açısından önemli değişmeler yaşanmıştır. Bu uygulama, girdilerin maliyetlerinin altında bir bedel ile üreticilere imkân sağlamasıyla sektörün en önemli ve maliyetli konularından biri olan gübre desteği verilmesine ve teknolojinin sektöre empoze edilmesine olanak sağlamıştır (Erkan, 2000: 22-25).

Tarımsal verimin doğa şartları ve teknolojik inovasyonlarla doğrudan bir ilişkisinin bulunması sektörde yeniliğin önemini ortaya koymaktadır. Türkiye birinci beş yıllık kalkınma plânında tarım sektörüne ayrı bir değer vurgusu yaparken, onuncu beş yıllık kalkınma plânında tarım sektörünün teknolojiyle bağdaşlaştırılması gerektiği üzerine vurgu yapmıştır. Tarım ve hayvancılık konuları bu plânlı dönemlerde ayrı bir öneme sahipken, tarımsal ar-ge, nanoteknoloji ve biyoteknoloji konularının geliştirilmesi gerektiğine değinmiştir (Alpagu, 2018: 46). 
Ekici, M. \& Tutar, F. (2022). Birincil Sektör Olarak Tarımın Dış Ticaretteki Stratejik Rolü.

Fiscaoeconomia, 6(1), 118-141. Doi: 10.25295/fsecon.991823

Tablo 1: Mazot ve Gübre Desteklemelerinin Birim Fiyatları

\begin{tabular}{|c|c|c|c|}
\hline Ürünler & $\begin{array}{l}\text { Mazot } \\
\text { (TL/da) }\end{array}$ & $\begin{array}{l}\text { Gübre } \\
\text { (TL/da) }\end{array}$ & $\begin{array}{l}\text { Toplam } \quad \text { Destek } \\
\text { (TL/da) }\end{array}$ \\
\hline $\begin{array}{l}\text { Buğday, Arpa, Çavdar, Yulaf } \\
\text { Tritikale }\end{array}$ & 22 & 20 & 42 \\
\hline Çeltik, Kütlü Pamuk & 68 & 8 & 76 \\
\hline 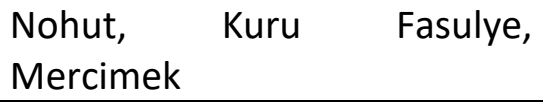 & 24 & 8 & 32 \\
\hline Kanola, Aspir & 20 & 8 & 28 \\
\hline Patates, Soya & 30 & 8 & 38 \\
\hline Yağlık Ayçiçeği & 29 & 8 & 37 \\
\hline Dane Mısır & 27 & 8 & 35 \\
\hline Kuru Soğan, Yem Bitkileri & 19 & 8 & 27 \\
\hline Yaş Çay, Fındık & 18 & 8 & 26 \\
\hline Zeytin & 17 & 8 & 25 \\
\hline Diğer Ürünler & 17 & 8 & 25 \\
\hline Nadas & 8 & & 8 \\
\hline
\end{tabular}

Kaynak: (Resmi Gazete, 2021).

Tablo 1 incelendiğinde çiftçilere tarım ürün grubuna göre dekar başına ödenecek mazot ve gübre desteklemeleri gösterilmektedir. Bu desteklemelerden faydalanabilmek için çiftçilerin Çiftçi Kayıt Sistemi'ne kayıt olmaları gerekmektedir.

Tarım politikalarının asıl hedefi üretimi desteklemek değil, verimliliği sağlamak ve doğal kaynakların sürdürülebilirlik seviyesini artırmak olmalıdır. 2014-2018 yıllarını kapsayan Onuncu Kalkınma Plânı'nda yer alan bir tanıma göre; tarımsal politikalar küresel olarak rekabetçi ve çevre dostu politikalar gütmelidir. 2018-2022 Gıda, Tarım ve Hayvancılık Bakanlığı Stratejik Plânında sürdürülebilir üretime, yeterli ve güvenilir gıdaya erişime, kırsal kalkınmaya ve sektörün rekabetçiliğini artırmaya yönelik hedeflere yer verilmiştir. 2018-2022 Stratejik Plânda yedi ayrı konu üzerinde durulmuştur. Bunlar (Tarım ve Orman Bakanlığı, 2019);

- $\quad$ Tarımsal üretim ve arz güvenliği.

- $\quad$ Gıda güvenliği.

- $\quad$ Bitki ve hayvan sağlığı, hayvan refahı.

- Tarımsal alt yapı ve kırsal kalkınma.

- $\quad$ Su ürünleri ve balıkçılık kaynakları yönetimi.

- Ar-Ge.

- $\quad$ Kurumsal kapasite geliştirme.

Gelişmiş ülke ekonomilerine bakıldığında tarımsal istihdamın toplam istihdam içindeki payı az olsa da sektöre önemli ölçüde tarımsal desteklemeler yapıldığından tarımın yeri bu gibi ülkelerde halâ önemini korumaktadır. Üretici sayısının az olması fakat elde edilen verimin fazla olması tarım sektörünün yeteneğini göstermektedir. Tarım teknolojisinin gelişmesi bu sektörü emek yoğun üretimden sermaye yoğun üretime geçilmesini sağlamıştır. Bu durum kırsal bölgelerde yaşayan kişilere olumsuz yansıyarak tarımsal istihdamı azaltsa da kalite ve verim açısından olumlu bir durum olarak değerlendirilebilir (Görmüş, 2019: 566). 
Ekici, M. \& Tutar, F. (2022). Birincil Sektör Olarak Tarımın Dış Ticaretteki Stratejik Rolü. Fiscaoeconomia, 6(1), 118-141. Doi: 10.25295/fsecon.991823

Tablo 2: Tahıl ve Diğer Bitkisel Ürün Fiyatları (TL/Kg)

\begin{tabular}{|l|l|l|l|l|l|l|l|l|l|}
\hline Yıllar & Arpa & Buğday & $\begin{array}{l}\text { Yeşil } \\
\text { Mercimek }\end{array}$ & Yulaf & Çavdar & Mısır & Tütün & Nohut & Pamuk \\
\hline $\mathbf{2 0 1 0}$ & 0.40 & 0.54 & 2.11 & 0.48 & 0.38 & 0.47 & 6.86 & 1.60 & 1.23 \\
\hline $\mathbf{2 0 1 1}$ & 0.48 & 0.59 & 2.07 & 0.62 & 0.45 & 0.63 & 9.40 & 2.11 & 1.88 \\
\hline $\mathbf{2 0 1 2}$ & 0.56 & 0.61 & 2.14 & 0.67 & 0.50 & 0.58 & 11.36 & 2.68 & 1.23 \\
\hline $\mathbf{2 0 1 3}$ & 0.60 & 0.67 & 2.11 & 0.71 & 0.57 & 0.61 & 10.80 & 2.46 & 1.35 \\
\hline $\mathbf{2 0 1 4}$ & 0.62 & 0.74 & 2.17 & 0.74 & 0.62 & 0.62 & 11.75 & 2.33 & 1.47 \\
\hline $\mathbf{2 0 1 5}$ & 0.65 & 0.78 & 2.64 & 0.78 & 0.65 & 0.66 & 13.79 & 2.61 & 1.32 \\
\hline $\mathbf{2 0 1 6}$ & 0.68 & 0.81 & 3.02 & 0.81 & 0.66 & 0.66 & 16.82 & 3.68 & 1.70 \\
\hline $\mathbf{2 0 1 7}$ & 0.78 & 0.89 & 3.26 & 0.87 & 0.73 & 0.75 & 16.28 & 5.46 & 2.01 \\
\hline $\mathbf{2 0 1 8}$ & 0.86 & 0.96 & 2.96 & 0.97 & 0.81 & 0.85 & 19.20 & 4.80 & 2.38 \\
\hline $\mathbf{2 0 1 9}$ & 1.07 & 1.22 & 3.44 & 1.22 & 1.01 & 1.02 & 21.50 & 3.41 & 2.68 \\
\hline $\mathbf{2 0 2 0}$ & 1.28 & 1.50 & 4.47 & 1.65 & 1.34 & 1.21 & 21.50 & 3.82 & 3.02 \\
\hline
\end{tabular}

Kaynak: (TUiK, 2021).

Tablo 2'de Türkiye'nin bazı tahıl ve bitkisel ürünlerinin değeri verilmiştir. Tarım sektöründe üretim maliyetleri gün geçtikçe artmaktadır. Bu maliyetler karşısında çiftçinin üretime devam edebilmesi için tarımsal desteklemelerin artırıması gerekmektedir. Çünkü üreticiler desteklendiği sürece üretim fazlası oluşturmak mümkün olmaktadır.

\section{Tarımsal Üretimde Verimlilik ve Tarımsal Dış Ticaret}

Tarım sektöründe ar-ge faaliyetlerinin gelişmesi tarımsal verimliliğin sağlanmasına yardımcı olmaktadır. Verimin aniden düşmesi; iklimde yaşanan değişimler, tarım arazilerinin bozulması ve aşınması, tarımsal girdi fiyatlarında artışlar, tarımsal hastalıklar ve haşereler gibi nedenlere bağlı olarak değişmektedir. Tarım ürünlerinde kalite ve miktar bazında bir artışın inovasyon faaliyetleri ile mümkün olacağı ifade edilmektedir. Tarımda yaşanan teknolojik adımlar ile kamu ve özel sektör kaynakları bu alana yönelerek üretimde verimlilik ve kârlılık sağlanmış olacaktır. Bu değişimler tarımda yeni dönüşümleri yaşatırken bir yandan da milli gelirin artmasını sağlayacaktır (Akyol ve Soyyiğit, 2021: 31).

Tarımsal üretimin iklimle doğrudan ilişkisinin olması bazı dönemlerde istikrarsızlığa yol açmaktadır. Bu durumda tarımsal gelirde dalgalanmalar ortaya çıkar ve üreticilerin refah içinde yaşaması zorlaşır. Bu yüzden devlet tarım sektörüne gereken desteklemeleri vermeli ve çiftçiliğe özendirmelidir. Tarımsal üretimde öncelikli hedef; çevresel, iktisadi ve sosyal olarak sürdürülebilirliğini sağlamaktır. Bu amaç gerçekleştirilirken toplumun arz ve talepleri de göz ardı edilmemelidir. Ülkedeki insanların yeterli, dengeli ve sağlıklı beslenebilmesi gerekliliği bir yana; tarımsal üretimde uluslararası düzeyde rekabet gücünün artırılıp, alt yapı iyileştirmelerine önem verilip üretimde kalitenin artırılması gerekmektedir. Her ne kadar tarım sektörünün milli gelir içerisindeki payı azalsa da sektörün diğer sektörlerle ve piyasayla doğrudan bağlantısı devam etmektedir. Bu piyasa bağlantısı; artan ülke nüfusuna gıda temin edebilmek, yapılan tasarrufların sanayiye yatırım olarak dönmesini sağlamak, tarımsal girdiler üreterek ticareti canlı tutmak, üretim fazlasını ihraç ederek gelir elde etmektir (Tokatlıŏlu, vd., 2018: 153-154). 
Ekici, M. \& Tutar, F. (2022). Birincil Sektör Olarak Tarımın Dış Ticaretteki Stratejik Rolü.

Fiscaoeconomia, 6(1), 118-141. Doi: 10.25295/fsecon.991823

\subsection{Tarımsal Üretimde Verimlilik}

Tarım sektörünün GSMH'deki yeri git gide azalmaktadır. Özellikle son 40 yılda bu kötü seyir devam etmektedir. 1980 'li yıllardan sonra azalış trendine giren tarım sektörünün payı \%20'nin altına düşmüştür. 2000'li yılların sonunda ise bu pay \%10'un altında seyir izlemiştir. Güçlü ekonomilere bakıldığında gelişmişlik seviyesi arttıkça tarımın GSMH'deki payı azalır. Bu durum tarımdaki katma değerin diğer sektörlere oranla daha düşük olması ve gelirdeki artışlarla beraber tüketim harcamalarının sınai mallara kayması ile açıklanır (Aydın, 2009: 5). Fakat Türkiye ekonomisinde bu durumun benimsenmesi büyük düzeyde üretim açıklarının yaşanmasına neden olmaktadır. Nüfusunun dinamik bir yapıya sahip olması üretim yapmayı zorunlu hale getiren bir faktördür. Çünkü gıdaya ihtiyaç gün geçtikçe artmaktadır. Tarımsal üretimin azalması ülkenin kendine yeterlilik düzeyini düşürerek insanların yeterli şekilde beslenebilmesinin önüne geçmektedir (Günaydın, 2009: 197).

Yerli tarımsal üretimin sanayide işlenerek katma değerli bir ürüne dönüştürülmesi sürecinde tarımsal sanayinin ve çalışanlarının büyük etkisi vardır. Bu etki tarımda makineleşme, sulama, verim ve kalite olarak kendini göstermektedir. Tarımda sürekliliğin sağlanması hem üretici açısından hem de tüketici açısından önemlidir. Sağlıklı ve ucuz gıdaya erişim tüketiciler açısından soyut değil somut bir durumu ifade etmektedir. Tüketicilerin de yerli üretimi tüketip destek vermesi tarımda kaliteli ürün üretilmesi konusunda teşvikkâr olacaktır (Erçakar, 2007).

Büyüme teorisi ve kalkınma ekonomisine her zaman konu olan tarımsal verimlilik, kentleşmeyi ve sanayileşmeyi de beraberinde getirecektir. Gıda ve tarımsal hammaddede belli bir üretim düzeyinin yakalanmasıyla verimlilik büyümesi gerçekleşecek olup; sınai büyümeyi de olumlu etkileyerek tarım sektöründe yeni bir üretim anlayışının yakalanmasına zemin hazırlayacaktır. Çünkü gelişmiş ülkelere bakıldığında sanayileşme ve kalkınma oranlarının bu denli iyi olmasının sebebi tarımda yaptıkları reform hareketlerdir. Diğer bir sorun ise tarımsal işletmelerin küçük ve çok parçalı olması sorunudur. Bu sorun büyük firmalara karşı rekabet edememeyi tetiklemektedir. Tarımsal üretim doğa koşullarından oldukça fazla etkilenir. Arz esnekliliğinin olmaması üretimde miktarı sınırlandırmaktadır. Kullanılan diğer üretim faktörlerinden emek ve sermaye artırılsa dahi yine tarımsal verimde çok sınırlı etkiye sahip olacaktır. Üretim plânlaması kavramı bu noktada önemsizleşmektedir. Çünkü etkin pazarlama organizasyon yapısının bulunmayışı üreticilerin fiyat belirsizliğine takılmasına yol açıp, iktisat literatüründe Örümcek Ağı Teoremi'nin (Cobweb Teoremi) yaşanmasına neden olmaktadır (Erçakar ve Taşçı, 2011: 172-176).

Organik tarım, biyodinamik tarım, kalıcı tarım (permakültür) ve hassas tarım (Özkan, 2016: 420) gibi birçok tarımsal modele sahip olan sektörde üreticiler emeğinin karşılı̆ını alamamaktadır. Bu sorun, gelecek sezonda yapılacak üretim faaliyetlerinin gerçekleştirilmesi hususunda çiftçileri zorlamaktadır. Tarımsal verim sadece kaliteli toprakla ilişkilendirilemez. Devlet destekleri, uygulanan politikalar, iç ve dış pazarın durumu, taban ve tavan fiyat uygulamaları, mazot ve gübre fiyatları, tarımsal aletlerin yaygın kullanımı gibi daha birçok faktörler tarımda hem verimliliği hem de kaliteyi belirmektedir. 
Ekici, M. \& Tutar, F. (2022). Birincil Sektör Olarak Tarımın Dış Ticaretteki Stratejik Rolü.

Fiscaoeconomia, 6(1), 118-141. Doi: 10.25295/fsecon.991823

\begin{tabular}{|c|c|c|c|c|c|c|c|c|c|c|c|c|}
\hline \multicolumn{13}{|c|}{ Tablo 3: Türkiye'de Tarım Alanları } \\
\hline \multirow{2}{*}{$\begin{array}{l}\text { Tarım } \\
\text { Alanı }\end{array}$} & \multicolumn{2}{|l|}{1990} & \multicolumn{2}{|l|}{2002} & \multicolumn{2}{|l|}{2017} & \multicolumn{2}{|l|}{2018} & \multicolumn{2}{|l|}{2019} & \multicolumn{2}{|l|}{2020} \\
\hline & Bin ha & $\%$ & Bin ha & $\%$ & Bin ha & $\%$ & Bin ha & $\%$ & Bin ha & $\%$ & Bin ha & $\%$ \\
\hline $\begin{array}{l}\text { Tarla } \\
\text { Bitkileri }\end{array}$ & 18.868 & 67,7 & 17.935 & 67,5 & 15.532 & 66,4 & 15.421 & 66,5 & 15.387 & 66,6 & 15.615 & 67,5 \\
\hline Nadas & 5.324 & 19,1 & 5.040 & 19,0 & 3.697 & 15,8 & 3.513 & 15,2 & 3.387 & 14,7 & 3.173 & 13,7 \\
\hline Sebze & 635 & 2,3 & 930 & 3,5 & 798 & 3,4 & 784 & 3,4 & 790 & 3,4 & 779 & 3,4 \\
\hline $\begin{array}{l}\text { Meyve, } \\
\text { İçecek } \\
\text { ve } \\
\text { Baharat }\end{array}$ & 3.029 & 10,9 & 2.674 & 10,1 & 3.343 & 14,3 & 3.457 & 14,9 & 3.525 & 15,3 & 3.564 & 15,4 \\
\hline $\begin{array}{l}\text { Süs } \\
\text { Bitkileri }\end{array}$ & - & - & - & - & 5 & 0,02 & 5.1 & 0,02 & 5.2 & 0,02 & 5 & 0,02 \\
\hline Toplam & 27.856 & 100 & 26.579 & 100 & 23.375 & 100 & 23.180 & 100 & 23.094 & 100 & 23.136 & 100 \\
\hline
\end{tabular}

Kaynak: (Tarım ve Orman Bakanlığı, 2021).

Tablo 3'e bakıldığında Türkiye' nin belirli yıl aralıklarında sahip olduğu tarım alanları verilmiştir. Tarım alanlarının giderek azaldığı tabloda dikkat çekmektedir. Nadasa bırakılan alanların azalması ise tarım sektöründe verimliliği ve kaliteyi düşürerek tarım arazilerinin daha çok yorulmasına neden olmaktadır.

\section{Şekil 1: Türkiye'de Tarımsal Üretim (Milyon Ton)}

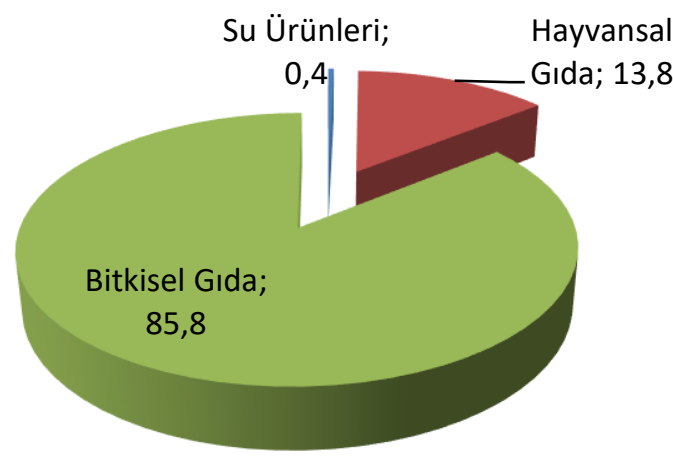

Kaynak: (Birişik, 2019: 70).

Şekil 1'de görüldüğü üzere Türkiye'de yaygın olarak bitkisel üretim gerçekleştirilmektedir. Hayvansal gıdanın aslında bitkisel üretimle yakından ilişkili olduğu bir gerçektir. Çünkü hayvancılıkta kullanılan yem, büyük oranda bitkisel üretimden karşılanmaktadır.

Tarımsal verimliliği ölçmek bir ülkenin üretimde ne gibi bir yol katettiğini de göstermektedir. Bu bağlamda verimliliği ölçmek için Dünya Bankası'nın açıkladığı yöntem; avcılık ve orman 
Ekici, M. \& Tutar, F. (2022). Birincil Sektör Olarak Tarımın Dış Ticaretteki Stratejik Rolü.

Fiscaoeconomia, 6(1), 118-141. Doi: 10.25295/fsecon.991823

ürünleri de dahil olmak üzere tarımsal tüm üretim ortalama girdi maliyetleri çıkarıldıktan sonra mülkiyet sahipliği aranmaksızın çalışan kişi başına bölünerek ortalama değer elde edilir. Dünyada bu rakam yani kişi başına çalışanın ürettiği yıllık katma değer ortalama 16.730 \$iken Türkiye'de bu rakam 10.922 \$ olarak hesaplanmıştır. Verimlilik açısından dünya ülkeleri sıralamasında 53. sırada yer almaktadır. Bu sıralama Türkiye'nin tarımsal verimlilikte sıkıntılar yaşadığını göstermektedir (Birişik, 2019: 72).

Tablo 4: Yıllara Göre Traktör ve Biçerdöver Sayısı

\begin{tabular}{|l|l|l|}
\hline Yıllar & Traktör Sayısı & Biçerdöver Sayısı \\
\hline 2001 & 948416 & 12053 \\
\hline 2002 & 970083 & 11539 \\
\hline 2003 & 997620 & 11721 \\
\hline 2004 & 1009065 & 11519 \\
\hline 2005 & 1022365 & 11811 \\
\hline 2006 & 1037383 & 12359 \\
\hline 2007 & 1056128 & 12775 \\
\hline 2008 & 1070746 & 13084 \\
\hline 2009 & 1073538 & 13360 \\
\hline 2010 & 1096683 & 13799 \\
\hline 2011 & 1125001 & 14313 \\
\hline 2012 & 1178253 & 14813 \\
\hline 2013 & 1213560 & 15486 \\
\hline 2014 & 1243300 & 15899 \\
\hline 2015 & 1260358 & 15998 \\
\hline 2016 & 1273531 & 16247 \\
\hline 2017 & 1306736 & 17199 \\
\hline 2018 & 1332139 & 17266 \\
\hline 2019 & 1354912 & 17190 \\
\hline
\end{tabular}

Kaynak: (TUiK, 2021).

Tablo 4'e bakıldığında tarım sektöründe yıllar itibariyle gelişen ve değişen traktör ve biçerdöver sayıları verilmiştir. 2001 yılından 2019 yılına kadar 400 binden fazla traktör sayısına ulaşılmıştır. Biçerdöver sayısında ise 5 binden fazla bir artış söz konusudur. Üretim yapılırken teknolojik alet ve makinaların kullanımı dönüm başına hem verimi artırmaktadır hem de hasatın kolaylıkla yapılıp zamandan tasarruf edilmesini sağlamaktadır.

\subsection{Tarımsal Dış Ticaret Verileri}

Bireylerin beslenme alışkanlıklarındaki değişim tarımsal ürünlerin işlenmesi gerekliliğini ortaya çıkarmıştır. Çünkü tarımsal üretimler çok dayanıklı mallar değildir. Dayanıkııı̆ının artırılması ve pazarlama olanaklarının geniş olması dış ticarette rekabeti canlandıracaktır. Gelişmekte olan ve sanayisi tarıma dayalı olan ülkelerde sanayinin büyük hamleler yapabilmesi için yeteri kadar hammaddeye sahip olması gerekmektedir. Bu hammaddenin temin edilmesi ise tarımda verimlilikle alakalı bir durumdur (Bayramoğlu, 2010: 59). 
Ekici, M. \& Tutar, F. (2022). Birincil Sektör Olarak Tarımın Dış Ticaretteki Stratejik Rolü.

Fiscaoeconomia, 6(1), 118-141. Doi: 10.25295/fsecon.991823

1981 yılından sonra tarımsal destekleme politikalarında daralmalar yaşanması üreticiyi sıkıntıya düşürerek üretim yapılmasını zorlaştırmıştır. 2003 yılından itibaren girdi ve fiyat destekleme uygulaması yerine doğrudan gelir desteğinin verilmeye başlanması ve bunun üretime yansıtılamaması bazı ürünlerde arz fazlası veya eksikliğinin görülmesine neden olmuştur. Sonuç olarak ithalatın ihracat rakamlarını geçmesi dışa bağımlılık oranını artırmaya başlamıştır. 2009 yılından sonra tarımda yaşanan bu olumsuzluk giderilmeye üretimde verimlilik anlayışııın kazanımının sağlanııması amaçlanmıştır (Çetin, 2020: 161-162). Tarım, 1980 yılına kadar işgücünün çoğunluğunu istihdam eden bir sektör konumundaydı. 1980 yılında tarım ürünleri, mal ticaretinin \%20'sini oluştururken bu rakam 2012 yılına gelindiğinde \%7 olarak belirlenmiştir. Sektörün yeniden yapılandırılması tarım dışı sektörler açısından olumlu bir gelişmedir. Türkiye ekonomisinde, tarımın dış ticaret ve ekonomik büyüme oranlarını geçmiş dönemlerde olduğu gibi yönlendiremediği ifade edilmektedir. Fakat ticarete konu olan tarım ürünlerinin verimlilik artışının sağlanması ve buna duyulan ihtiyacın gün geçtikçe artması tarım sektörünün stratejik önemini ortaya koymaktadır (Larson, vd., 2014: 67).

Tablo 5: Türkiye'de Dönemlere Göre Tarım Sektörü Büyüme Oranları

\begin{tabular}{|l|l|}
\hline Dönemler & $\begin{array}{l}\text { Tarım Sektörü } \\
\text { Büyüme Oranı } \\
\text { (\%) }\end{array}$ \\
\hline $2019-I$ & 2,5 \\
\hline $2019-I I$ & 3,4 \\
\hline $2019-I I I$ & 3,8 \\
\hline $2019-I V$ & 3,3 \\
\hline $2020-I$ & 3,0 \\
\hline $2020-I I$ & 4,0 \\
\hline $2020-$ III & 6,4 \\
\hline $2020-I V$ & 4,8 \\
\hline $2021-I$ & 7,5 \\
\hline $2021-I I$ & 2,3 \\
\hline
\end{tabular}

Kaynak: (TUIK, 2021).

Tarım sektörünün büyümesi ve gelişmesi Türkiye'nin uluslararası alanlarda rekabet edilebilirliğini artırmaktadır. Tablo 5'e bakıldığında GSYiH'nin iktisadi faaliyet kollarından biri olan tarım sektörünün dönemsel büyüme oranları yüzdesel olarak gösterilmektedir. Bu oranlar bir önceki yılın aynı çeyreğine göre artışları ifade etmektedir. Gelişmekte olan bir ülke için bu büyüme oranları yeterli seviyede değildir. Çünkü nüfusun sürekli artması ve gelişen sanayinin ham maddeye olan ihtiyacı bu oranların artırılması gerektiğini göstermektedir.

Tarım sadece kendi alanıyla sınırlı kalmayan bir sektördür. Ekonomik alanların hemen hemen hepsiyle doğrudan veya dolaylı ilişkiler kurmaktadır. Özellikle tekstil, deri, gıda, giyim ve tütün gibi alanlara sanayi girdisi sağlamaktadır. Bunun yanı sıra; lojistik, toptancılar, lokantalar, oteller ve parekendeciler gibi birçok alanla yakından ilişkilidir. Herşeyden önce bir üretim faktörüne sahip olan sektör ekonominin bütün göstergelerini birebir etkileme gücüne sahiptir. Tarım sektörünün sermaye biriktirme kaynağı olması sanayi sektörü için en temel üretim 
Ekici, M. \& Tutar, F. (2022). Birincil Sektör Olarak Tarımın Dış Ticaretteki Stratejik Rolü.

Fiscaoeconomia, 6(1), 118-141. Doi: 10.25295/fsecon.991823

kaynağını oluşturur. Bu yüzden iki sektör ayrılmaz bir puzzle parçasıdır. Türkiye'de tarımsal alandaki farklılaşmalarla birlikte sektörün GSMH içindeki payının git gide düştüğü gözlemlenmektedir. Bu düşüş trendi tarımsal dış ticareti olumsuz etkileyerek ihracatın ithalatı karşılama oranını düşürmektedir (Güngül ve Yenilmez, 2019: 961-962).

2021 yılının ilk ayında tarım, gıda ve içecek sektöründe 1,63 milyar dolar ihracat gerçekleştirilirken, 1,39 milyar dolar ise ithalat gerçekleştirilmiştir. 2021'in Ocak ayında tarım sektörünün dış ticaret dengesi önceki yılın aynı dönemine göre \% 38,4 oranında gerileme yaşamıştır. Dış ticarette katma değerli ürünlerin ihracatı ekonomiye ayrı bir artı sağlamaktadır. 2021 yılının Ocak ayında dış ticarette en fazla ihracatı yapılan katma değerli ürünler sırasıyla; fındık içi 127,7 milyon dolar, un 85,2 milyon dolar ve mandalina 57,1 milyon dolardır. Bu mallar toplam ihracatın \% 16,6'sını oluşturmuştur. Aynı dönemde en çok ithal edilen tarım ürünleri ise; buğday 188,8 milyon dolar, soya fasülyesi 102,3 milyon dolar ve ayçiçek yağı 58 milyon dolardır (TGDF, 2021).

\section{Şekil 2: 2014-2020 Yılı Tarım, Gıda ve İçecek îhracatı (Milyar Dolar)}

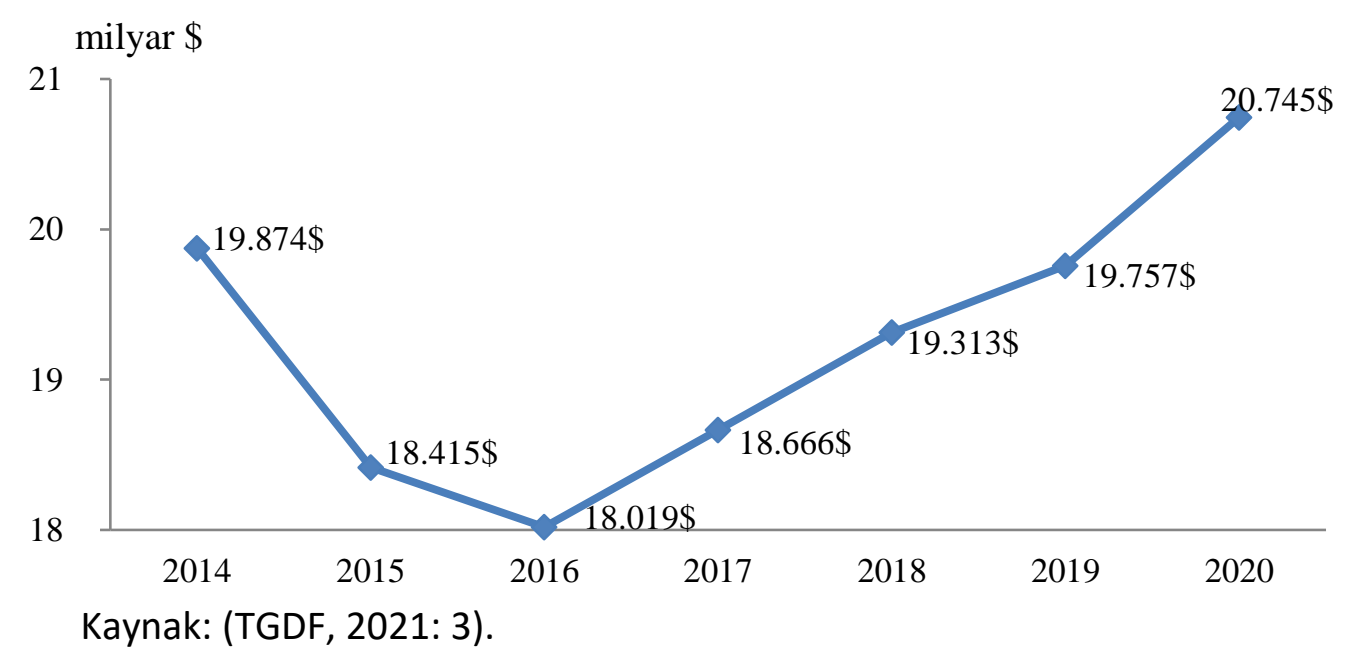

Şekil 2'ye bakıldığında 2014-2016 yılları arasında tarım, gıda ve içecek sektöründeki ihracat hızının azaldığı görülmektedir. Bu azalış trendi 2017 yılından sonra artış trendi olarak devam etmiştir. Bu artış döviz girdisine katkı, diğer sektörlere iş gücü ve sermaye transferi olarak kendini göstermektedir. Ekonomideki payı azalsa da olumlu katkıları devam eden bir sektördür. 
Ekici, M. \& Tutar, F. (2022). Birincil Sektör Olarak Tarımın Dış Ticaretteki Stratejik Rolü.

Fiscaoeconomia, 6(1), 118-141. Doi: 10.25295/fsecon.991823

\section{Şekil 3: 2014-2020 Yılı Tarım, Gıda ve İçecek İthalatı (Milyar \$)} milyar \$

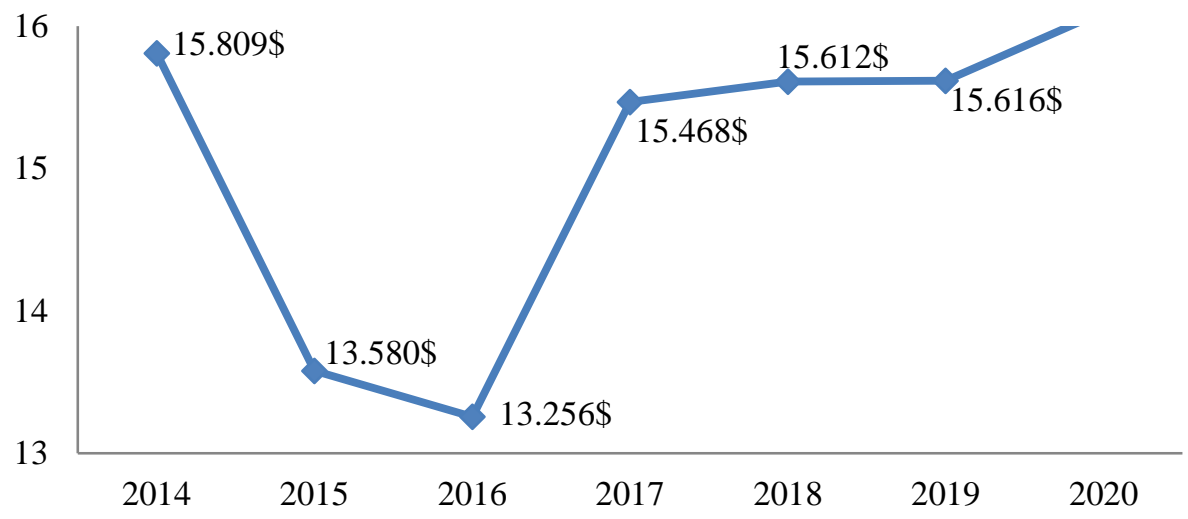

Kaynak: (TGDF, 2021: 3).

Şekil 3 incelendiğinde Türkiye'nin 2014-2020 yılları arasındaki tarım, gıda ve içecek ithalat rakamları milyar dolar cinsinden verilmiştir. 2015-2016 yılları arasında ithalatta bir düşüş olduğu görülse de sonraki yıllarda artış trendine girmiştir. Bu durum dış ticaret dengesine olumsuz yansıyacaktır. Özellikle gelişmekte olan ülke ekonomileri aradaki kur farkından dolayı bu dengesizliği daha çok hissetmektedir.

Tablo 6: Tahıllar (Toplam) Üretimi ve Dış Ticaret Rakamları (Ton)

\begin{tabular}{|l|l|l|l|}
\hline Piyasa Yılı & Üretim & ithalat & İhracat \\
\hline $\mathbf{2 0 1 0 / 2 0 1 1}$ & 31912550 & 4565386 & 3399462 \\
\hline $\mathbf{2 0 1 1 / 2 0 1 2}$ & 34302073 & 4424253 & 4395131 \\
\hline $\mathbf{2 0 1 2 / 2 0 1 3}$ & 32497430 & 5536328 & 4149281 \\
\hline $\mathbf{2 0 1 3 / 2 0 1 4}$ & 36589268 & 5646172 & 5178228 \\
\hline $\mathbf{2 0 1 4 / 2 0 1 5}$ & 31884157 & 8784623 & 4879666 \\
\hline $\mathbf{2 0 1 5 / 2 0 1 6}$ & 37717138 & 4837640 & 6588743 \\
\hline $\mathbf{2 0 1 6 / 2 0 1 7}$ & 34361164 & 5850339 & 8238485 \\
\hline $\mathbf{2 0 1 7 / 2 0 1 8}$ & 35232767 & 9828679 & 8238796 \\
\hline $\mathbf{2 0 1 8 / 2 0 1 9}$ & 33468699 & 10315018 & 9484113 \\
\hline $\mathbf{2 0 1 9 / 2 0 2 0}$ & 33401704 & 15209662 & 8440029 \\
\hline
\end{tabular}

Kaynak: (TUiK, 2021). 
Ekici, M. \& Tutar, F. (2022). Birincil Sektör Olarak Tarımın Dış Ticaretteki Stratejik Rolü.

Fiscaoeconomia, 6(1), 118-141. Doi: 10.25295/fsecon.991823

\begin{abstract}
Tablo 6'ya bakıldığında tahılların toplam dönemsel üretimi ton cinsinden verilmiştir. İthalatın ihracattan fazla olduğu dönemlerde dış ticaret dengesinde değişmelerin yaşanması mutlak bir sonuç olacaktır. Dönemlere bakıldığında üretimin fazla yapıldığı yıllar arasında ithalat rakamlarının düştüğü, ihracat rakamlarının ise yükseldiği görülmektedir.
\end{abstract}

Türkiye 2020 dış ticaret verileri incelendiğinde tarım, gıda ve içecek sektörü 20,7 milyar dolar ihracat, 16,1 milyar dolar ithalat gerçekleştirmiştir. Dış ticaret dengesi ise 4,64 milyar dolardır. Türkiye toplam 207 ülkeyle ihracat yapmaktadır. En çok ihracat yapılan ülkeler ise; Irak 2,9 milyar dolar, Almanya 1,6 milyar dolar, Rusya 1,4 milyar dolar, ABD 1,1 milyar dolar ve i̇talya 0,8 milyar dolardır. Bu ülkelere yapılan ihracat, toplam ihracatın \% 38' ini ifade etmektedir. 173 ülke ile de ithalatını gerçekleştirmektedir. En çok ithalat yapılan ilk beş ülke ise; Rusya 3,2 milyar dolar, Brezilya 1,4 milyar dolar, Ukrayna 1 milyar dolar, ABD 0,9 milyar dolar ve Malezya 0,6 milyar dolardır. Bu ülkelerden yapılan ithalat, toplam ithalatın $\% 44,6$ 'sını oluşturmaktadır (TGDF, 2021: 1-6).

Baklagillerin bir türü olan nohutta ihtiyaçtan fazlası bir üretim yapıldığında ülke ekonomisine katkısı rakamlarla ifade edilecek olunursa; Türkiye son 5 yılda yaklaşık olarak 322 milyon 908 bin dolarlık ihracat yapmıştır. 2020 yılında ise nohut ihracatı 77,7 milyon dolara ulaşmış olması dış ticarette pazarlama olanaklarının bu üründe iyi olduğunu göstermektedir. 2020 nohut ithalatı 2019 yılına göre \% 32,9 yükselerek 16 milyon 893 bin dolara yükselmiştir. Son 5 yılda nohutun oluşturduğu dış ticaret hacmi 641 milyon 739 bin dolardır (TMO, 2021: 26-27).

Dış ticaret verileri analizi yapılırken belli yöntemler kullanılmaktadır. Bunlardan biri; ISIC Rev.3'tür (International Standart Industrial Classification of all Economics Activities, Revision.3). Bu yöntem Tüm Ekonomik Faaliyetlerin Endüstri Sınıflaması Uluslararası Standardı olarak adlandırılmaktadır. Türkiye İstatistik Kurumu (TÜiK) tarafından bu yöntem kullanılmaktadır. Bazı ürünlerin hammadde kısmı tarım başlığı içinde yer almaktadır. Sanayi tarafından işlenmiş hali ise tarım dışında farklı bir başlıkta tutulmaktadır. Bu durum pek de sağlıklı sonuçlar vermemektedir. İkinci yöntem ise; SITC Rev.3'tür (Standart International Trade Classification, Revisions.3). Bu yöntem Standart Uluslararası Ticaret Sınıflandırması olarak isimlendirilir. SITC yöntemi araştırmacılar tarafından daha çok kullanılmaktadır. Çünkü ISIC'ta yer almayan tarım ürünlerinin bu yöntemde dahil edildiği görülmektedir. İkinci bir olumlu yanı ise; dış ticarette kullanılan tarımsal hammaddeleri gıda ve işlenmiş ürün şeklinde ayrıntılı başlıkta göstermesidir (Aydın ve Aydın, 2018: 119-120). 
Ekici, M. \& Tutar, F. (2022). Birincil Sektör Olarak Tarımın Dış Ticaretteki Stratejik Rolü.

Fiscaoeconomia, 6(1), 118-141. Doi: 10.25295/fsecon.991823

Tablo 7: Tarımsal Hammadde Dış Ticaretinin Sektörlere Göre Dağılımı (Bin \$)

\begin{tabular}{|c|c|c|c|c|c|c|}
\hline Alt Sektörler & 2014 & 2015 & 2016 & 2017 & 2018 & 2019 \\
\hline $\begin{array}{l}\text { Dokuma } \\
\text { ely.ve } \\
\text { artıkları } \\
\text { ihracatı }\end{array}$ & 333146 & 345242 & 358193 & 340640 & 402834 & 346550 \\
\hline $\begin{array}{l}\text { Dokuma } \\
\text { ely.ve } \\
\text { artıkları } \\
\text { ithalatı }\end{array}$ & 3094256 & 2469096 & 2485056 & 3073983 & 2770202 & 2890794 \\
\hline $\begin{array}{l}\text { Ticaret } \\
\text { Dengesi }\end{array}$ & $\begin{array}{l}-2761 \\
110\end{array}$ & $\begin{array}{l}-2123 \\
854\end{array}$ & $\begin{array}{l}-2126 \\
863\end{array}$ & $\begin{array}{l}-2733 \\
343\end{array}$ & $\begin{array}{l}-2367 \\
368\end{array}$ & $\begin{array}{l}- \\
2544244\end{array}$ \\
\hline $\begin{array}{l}\text { İşlenme.deri, } \\
\text { kösele ve } \\
\text { kürk ihracatı }\end{array}$ & 4630 & 2319 & 1533 & 2684 & 1544 & 2544 \\
\hline $\begin{array}{l}\text { İşlenme.deri, } \\
\text { kösele ve } \\
\text { kürk ithalatı }\end{array}$ & 242475 & 100044 & 80227 & 112882 & 128374 & 112058 \\
\hline $\begin{array}{l}\text { Ticaret } \\
\text { Dengesi }\end{array}$ & -237845 & -97725 & -78694 & -110198 & -126830 & -109514 \\
\hline $\begin{array}{l}\text { Kağ.ham.ve } \\
\text { kul. kağıt } \\
\text { ihracatı }\end{array}$ & 34836 & 24259 & 23991 & 21826 & 32568 & 56902 \\
\hline $\begin{array}{l}\text { Kağ.ham.ve } \\
\text { kul.kağıt } \\
\text { ithalatı }\end{array}$ & 683453 & 737712 & 742892 & 949662 & 1088463 & 1001006 \\
\hline $\begin{array}{l}\text { Ticaret } \\
\text { Dengesi }\end{array}$ & -648614 & -713453 & -718901 & -927836 & $\begin{array}{l}-1055 \\
895\end{array}$ & -944104 \\
\hline $\begin{array}{l}\text { B.Y.B. } \\
\text { işlenme. } \\
\text { hay. ve bitki. } \\
\text { hammadde } \\
\text { ihracatı }\end{array}$ & 213187 & 182679 & 192102 & 198808 & 235914 & 261828 \\
\hline $\begin{array}{l}\text { B.Y.B. } \\
\text { işlenme. } \\
\text { hay. ve bitki. } \\
\text { hammadde } \\
\text { ithalatı }\end{array}$ & 360284 & 332147 & 329277 & 345829 & 324453 & 295387 \\
\hline $\begin{array}{l}\text { Ticaret } \\
\text { Dengesi }\end{array}$ & -147097 & -149468 & -137175 & -147021 & -88539 & -33559 \\
\hline
\end{tabular}


Ekici, M. \& Tutar, F. (2022). Birincil Sektör Olarak Tarımın Dış Ticaretteki Stratejik Rolü. Fiscaoeconomia, 6(1), 118-141. Doi: 10.25295/fsecon.991823

\begin{tabular}{|l|l|l|l|l|l|l|}
\hline $\begin{array}{l}\text { Mantar, } \\
\text { odun } \\
\text { kereste } \\
\text { ihracatı }\end{array}$ & 34117 & 27788 & 22949 & 27963 & 37007 & 65240 \\
\hline $\begin{array}{l}\text { Mantar, } \\
\text { odun ve } \\
\text { kereste } \\
\text { ithalatı }\end{array}$ & 659586 & 740695 & 589497 & 529810 & 476558 & 204298 \\
\hline $\begin{array}{l}\text { Ticaret } \\
\text { Dengesi }\end{array}$ & -625469 & $-\mathbf{7 1 2} 907$ & -566548 & -501847 & -439551 & -139058 \\
\hline $\begin{array}{l}\text { Ham kauçuk } \\
\text { ihracatı }\end{array}$ & 51177 & 36795 & 37791 & 45256 & 49124 & 44781 \\
\hline $\begin{array}{l}\text { Ham kauçuk } \\
\text { ithalatı }\end{array}$ & 971014 & 790062 & 711291 & 990907 & 967639 & 888019 \\
\hline $\begin{array}{l}\text { Ticaret } \\
\text { Dengesi }\end{array}$ & -919837 & $-\mathbf{7 5 3 2 6 7}$ & -673900 & -945651 & -918515 & -843238 \\
\hline
\end{tabular}

Kaynak: (TUIK, 2020). Not: Standart Uluslararası Ticaret Sınıflamasına (SITC Rev.3) göre hazırlanan veriler kullanılmıştır. Ticaret Dengesi yazar tarafından hesaplanmıştır.

Tablo 7'ye bakıldığında Türkiye'nin tarımsal hammaddelerinin alt sektörlere ayrıldığı görülmektedir. Tabloda bu sektördeki ürünlerin ihracat ve ithalat rakamlarına dolar cinsinden yer verilmiştir.

Tablo 7'de en fazla ithalatın dokuma elyafları ve bunların artıkları oluşturmaktadır. Bu durumun sebebi hazırgiyim ve konfeksiyon ihracatının artmasından kaynaklanmaktadır. 2021 yılının Ocak-Mart döneminde 2020 yııının aynı dönemine kıyasla \% 11,6 oranında artış trendi göstererek 4,1 milyar dolarlık ihracat gerçekleştirilmiştir (ITKIB, 2021: 2). Bu tablodan tarımsal hammaddede dışa bağımlı bir ülke profili çizilmektedir. Hammaddede dışa bağımlıı̆̆ı azaltmak ve yerli üreticiyi korumak dış ticaret dengesindeki bu negatif işaretleri pozitif yapmaya yetecektir. Bu dışa bağımlılık sorunu sanayi alanında kaynak olarak kullanılan bazı malların temin edilmesinde yani ihracatın sürekliliğinde sıkıntılar yaşanmasına neden olabilir. Küresel piyasalarda da ekstra bir maliyet oluşturması rekabet edilebilirliği minimuma indirmektedir. Yani üretmek ve ihracat arasında uyumun olması dış ticarete olumlu yansıyacak bir durumdur. Üreticilerin, bu malları işleyen gıda sanayisinin ve ihracatçı firmaların uzun dönemli ve inovasyonlu tarım-gıda politikasını hayata geçirmesi gerekmektedir (Yağcıoğlu, 2015: 9-11). 
Ekici, M. \& Tutar, F. (2022). Birincil Sektör Olarak Tarımın Dış Ticaretteki Stratejik Rolü.

Fiscaoeconomia, 6(1), 118-141. Doi: 10.25295/fsecon.991823

\section{Tablo 8: Gıda Maddeleri Dış Ticaretinin Alt Sektörlere Göre Dağılımı (Bin \$)}

\begin{tabular}{|c|c|c|c|c|c|c|}
\hline Alt Sektörler & 1996 & 2000 & 2005 & 2010 & 2015 & 2019 \\
\hline $\begin{array}{l}\text { Et ve et ürünleri } \\
\text { ihracatı }\end{array}$ & 27192 & 13395 & 41315 & 236688 & 487908 & 665423 \\
\hline $\begin{array}{l}\text { Et ve et ürünleri } \\
\text { ithalatı }\end{array}$ & 26023 & 1759 & 778 & 251235 & 115494 & 29635 \\
\hline Ticaret Dengesi & 1169 & 11636 & 40537 & -14547 & 372414 & 635788 \\
\hline $\begin{array}{l}\text { Süt,süt ürünleri } \\
\text { ve yumurta } \\
\text { ihracatı }\end{array}$ & 36821 & 21733 & 80839 & 324180 & 544045 & 652032 \\
\hline $\begin{array}{l}\text { Süt,süt ürünleri } \\
\text { ve yumurta } \\
\text { ithalatı }\end{array}$ & 42770 & 36919 & 78397 & 139461 & 160937 & 120372 \\
\hline Ticaret Dengesi & -5949 & -15186 & 2442 & 184719 & 383108 & 531660 \\
\hline $\begin{array}{l}\text { Balık ve } \\
\text { diğ.deniz } \\
\text { ürünleri ihracatı }\end{array}$ & 101466 & 88643 & 243209 & 340008 & 687155 & 1009371 \\
\hline $\begin{array}{l}\text { Balık ve } \\
\text { diğ.deniz } \\
\text { ürünleri ithalatı }\end{array}$ & 35536 & 37339 & 69193 & 137034 & 249811 & 189391 \\
\hline Ticaret Dengesi & 65930 & 51304 & 174016 & 202974 & 437344 & 819980 \\
\hline $\begin{array}{l}\text { Hub. ve } \\
\text { hububat } \\
\text { ürünleri ihracatı }\end{array}$ & 507463 & 406081 & 891873 & $\begin{array}{l}1 \\
782194\end{array}$ & 2663355 & 3115849 \\
\hline $\begin{array}{l}\text { Hub. ve } \\
\text { hububat } \\
\text { ürünleri ithalatı }\end{array}$ & 787669 & 408267 & 226296 & $\begin{array}{l}1 \\
169797\end{array}$ & 1807631 & 3362817 \\
\hline Ticaret Dengesi & -280206 & -2186 & 665577 & 612397 & 855724 & -246968 \\
\hline $\begin{array}{l}\text { Meyve ve sebze } \\
\text { ihracatı }\end{array}$ & $\begin{array}{l}2 \\
218856\end{array}$ & $\begin{array}{l}1 \\
816866\end{array}$ & $\begin{array}{l}4 \\
373567\end{array}$ & $\begin{array}{l}6 \\
152501\end{array}$ & 7651338 & 7291177 \\
\hline $\begin{array}{l}\text { Meyve ve sebze } \\
\text { ithalatı }\end{array}$ & 100535 & 193031 & 284147 & 757297 & 1151523 & 969473 \\
\hline Ticaret Dengesi & $\begin{array}{l}2118 \\
321 \\
\end{array}$ & $\begin{array}{l}1623 \\
835 \\
\end{array}$ & $\begin{array}{l}4089 \\
420 \\
\end{array}$ & $\begin{array}{l}5395 \\
204 \\
\end{array}$ & 6499815 & 6321704 \\
\hline $\begin{array}{l}\text { Şeker,şek.ürün. } \\
\text { ve bal ihracatı }\end{array}$ & 211028 & 238724 & 211427 & 395561 & 583378 & 643831 \\
\hline $\begin{array}{l}\text { Şeker,şek.ürün. } \\
\text { ve bal ithalatı }\end{array}$ & 293515 & 15604 & 45987 & 52891 & 166079 & 171500 \\
\hline Ticaret Dengesi & -82487 & 223120 & 165440 & 342670 & 417299 & 472331 \\
\hline
\end{tabular}


Ekici, M. \& Tutar, F. (2022). Birincil Sektör Olarak Tarımın Dış Ticaretteki Stratejik Rolü.

Fiscaoeconomia, 6(1), 118-141. Doi: 10.25295/fsecon.991823

\begin{tabular}{|l|l|l|l|l|l|l|}
\hline $\begin{array}{l}\text { Kahve,çay,kaka } \\
\text { o,bah.ve } \\
\text { ürünleri ihracatı }\end{array}$ & 144323 & 139639 & 309356 & 537823 & 744351 & 838590 \\
\hline $\begin{array}{l}\text { Kahve,çay,kaka } \\
\text { o,bah.ve } \\
\text { ürünleri ithalatı }\end{array}$ & 106404 & 124031 & 275447 & 519732 & 767564 & 894640 \\
\hline Ticaret Dengesi & $\mathbf{3 7 9 1 9}$ & $\mathbf{1 5 6 0 8}$ & $\mathbf{3 3 9 0 9}$ & $\mathbf{1 8 0 9 1}$ & $\mathbf{- 2 3 2 1 3}$ & $\mathbf{- 5 6 0 5 0}$ \\
\hline $\begin{array}{l}\text { Hayvanlar için } \\
\text { gıda maddeleri } \\
\text { ihracatı }\end{array}$ & 14567 & 10480 & 17583 & 31141 & 115932 & 233584 \\
\hline $\begin{array}{l}\text { Hayvanlar için } \\
\text { gıda maddeleri } \\
\text { ithalatı }\end{array}$ & 149727 & 206610 & 341484 & 741318 & 1116741 & 1539380 \\
\hline \begin{tabular}{l} 
Ticaret Dengesi \\
\hline
\end{tabular} & $\mathbf{- 1 3 5 1 6 0}$ & $\mathbf{- 1 9 6 1 3 0}$ & $\mathbf{- 3 2 3 9 0 1}$ & $\mathbf{- 7 1 0 1 7 7}$ & $\begin{array}{l}\mathbf{- 1} 000 \\
\mathbf{8 0 9}\end{array}$ & $\begin{array}{l}\mathbf{- 1 3 0 5} \\
\mathbf{7 9 6}\end{array}$ \\
\hline
\end{tabular}

Kaynak: (TUIK, 2020). Not: Standart Uluslararası Ticaret Sınıflamasına (SITC Rev.3) göre hazırlanan veriler kullanılmıştır. Ticaret Dengesi yazar tarafından hesaplanmıştır.

Tablo 8'e bakıldığında 1996-2000 yılları arasında üretim kapasitesinin düşük olduğu görülmektedir. 2005 yılından sonra hemen hemen her gıda ürününde bir sıçrama olmuştur. ihracatın ithalattan fazla olduğu her yıl, ekonominin dış ticarette güzel başarılar elde ettiğini göstermektedir. Fakat tabloda özellikle hayvanlar için gıda maddeleri ihracatının ithalattan hep az olduğu ve eksi değer aldığı görülmektedir. Bu durum yem sanayisinde dışa bağımlı bir resim çizmektedir.

\subsection{Tarımsal Üretim ve Dış Ticaret Açısından Türkiye'nin SWOT Analizi}

Bitkisel üretim sektöründe yaşanan herhangi bir gelişme yada faktör Türkiye'nin tarım sektöründe yaşayabileceği güçlü veya zayıf yönü göstermektedir. Türkiye'de yaşanan konjonktürel gelişmeler bu yönlerin zayıf yada güçlü olmasını belirleyen etkendir. Bu bağlamda Türkiye'nin bitkisel üretimde ve bunların dış ticaretinde karşılaştığı güçlü ve zayıf yönler, fırsatlar ve tehditler (SWOT Analizi) Tablo 9 ve Tablo 10'da gösterilmektedir.

Tablo 9: Güçlü/Zayıf Yönler

\begin{tabular}{|l|l|}
\hline Güçlü Yönler & Zayıf Yönler \\
\hline Ekolojik yapısı ve ürün çeşitliliği & $\begin{array}{l}\text { Arazilerin çok parçalı, işletmelerin küçük } \\
\text { olması }\end{array}$ \\
\hline Bölgesel konum ve lojistik imkânları & Girdi maliyetlerinin yüksek olması \\
\hline $\begin{array}{l}\text { Dünyada bazı ürünlerde ilk sıralarda } \\
\text { olması }\end{array}$ & Tarımsal üretimde plânlama eksikliği \\
\hline $\begin{array}{l}\text { Bitkisel üretimde iTU ve organik tarım } \\
\text { sistemlerinin benimsenmeye başlaması }\end{array}$ & Girdi kullanımında dışa bağımlılık \\
\hline Tarımsal desteklemeler & $\begin{array}{l}\text { Üretici organizasyonlarının etkin ve güçlü } \\
\text { olmaması }\end{array}$ \\
\hline $\begin{array}{l}\text { Tarım sektöründe Ar-Ge faaliyetlerinin } \\
\text { varlığı }\end{array}$ & Ar-Ge'ye yeteri kadar kaynak ayrılmaması \\
\hline
\end{tabular}


Ekici, M. \& Tutar, F. (2022). Birincil Sektör Olarak Tarımın Dış Ticaretteki Stratejik Rolü. Fiscaoeconomia, 6(1), 118-141. Doi: 10.25295/fsecon.991823

\begin{tabular}{|l|l|}
\hline $\begin{array}{l}\text { Sanayinin talebine uygun bitkisel üretimin } \\
\text { yapılması }\end{array}$ & Bitki ıslahında yetersizlikler \\
\hline $\begin{array}{l}\text { Gıda, Tarım ve Hayvancılık Bakanlığı'nın } \\
\text { yaygın teşkilat ağı }\end{array}$ & Teknoloji kullanımının yetersiz olması \\
\hline $\begin{array}{l}\text { Tarımsal sanayinin gelişmesine yönelik } \\
\text { yatırımların varlığı }\end{array}$ & $\begin{array}{l}\text { Depolama ve pazarlama olanaklarının } \\
\text { yetersiz kalması }\end{array}$ \\
\hline Devlet destekli tarım sigortalarının varlığı & Üretim tekniklerinin yanlış kullanılması \\
\hline Kalifiyeli elemanlara sahip olması & $\begin{array}{l}\text { Sertifikalı tohum ve fidan kullanımının } \\
\text { yetersizliği }\end{array}$ \\
\hline & Tarladan sofraya izlenebilirliğin yetersizliği \\
\hline & $\begin{array}{l}\text { Karar destek mekanizması yönüyle tarım } \\
\text { bilgi sistemlerinde entegre sağlanamaması }\end{array}$ \\
\hline & $\begin{array}{l}\text { Tarım ürünlerinde piyasa düzenleme ve } \\
\text { müdahale kuruluşlarının yetersizliği }\end{array}$ \\
\hline
\end{tabular}

Kaynak: (Kalkınma Bakanlığı, 2018).

Tablo 10: Firsatlar ve Tehditler

\begin{tabular}{|l|l|}
\hline Fırsatlar & Tehditler \\
\hline $\begin{array}{l}\text { İklim çeşitliliğine sahip olması, biyoçeşitlilik } \\
\text { imkânı }\end{array}$ & Küresel iklim değişiklikleri \\
\hline $\begin{array}{l}\text { Geleneksel ve yöresel ürünlere sahip } \\
\text { olması }\end{array}$ & $\begin{array}{l}\text { Tarımsal arazilerin yanlış kullanımı ve miras } \\
\text { yoluyla bölünmesi }\end{array}$ \\
\hline $\begin{array}{l}\text { Biyoteknoloji ve malzeme biliminin } \\
\text { üretimde verimliliği olumlu etkilemesi }\end{array}$ & $\begin{array}{l}\text { Tarımsal destekleme politikalarında ve } \\
\text { stratejilerinde yaşanan eksiklikler }\end{array}$ \\
\hline $\begin{array}{l}\text { Büyüyen Avrupa ve Ortadoğu pazarında } \\
\text { Türkiye'nin önemli bir tedarikçi ve coğrafi } \\
\text { konumunda olması }\end{array}$ & Gıda fiyatlarının dalgalanması \\
\hline $\begin{array}{l}\text { Gelişmeye açık bir sektör ve dış pazar } \\
\text { potansiyelinin geniş olması }\end{array}$ & Kırsal kesimden şehirlere göç edilmesi \\
\hline $\begin{array}{l}\text { Üretici ve tüketici bilincinin artması } \\
\text { İç ve dış talebin sürekli artması }\end{array}$ & $\begin{array}{l}\text { Sürdürülebilir girdi (hammadde vb.) } \\
\text { sağlayamama }\end{array}$ \\
\hline $\begin{array}{l}\text { Yeni üretim modellerinin geliştiriliyor } \\
\text { olması }\end{array}$ & $\begin{array}{l}\text { Küresel piyasa koşullarında rekabet } \\
\text { edilebilir hammadde temin edememe } \\
\text { yaşanması gıda fiyatlarında spekülasyon }\end{array}$ \\
\hline $\begin{array}{l}\text { Uluslararası gıda standartlarının ihracata } \\
\text { olumlu etkisi }\end{array}$ & $\begin{array}{l}\text { Üretim ve hammadde temininde enerji } \\
\text { maliyetlerinin yüksek olması }\end{array}$ \\
\hline & \begin{tabular}{l} 
Ar-Ge yatırımlarının yetersiz olması \\
\hline
\end{tabular}
\end{tabular}

Kaynak: (Kalkınma Bakanlığı, 2018).

Tablo 9 ve 10'a bakıldığında Türkiye'nin tarım sektörüne yönelik bir yenileşme faaliyetlerini başlatması gerektiği görülmektedir. Tarım arazileri bakımından geniş bir hektara sahip olan Türkiye'nin bu durumu avantaja çevirmesi üretimin sürekliliğini sağlayacaktır. Sektöre 
Ekici, M. \& Tutar, F. (2022). Birincil Sektör Olarak Tarımın Dış Ticaretteki Stratejik Rolü.

Fiscaoeconomia, 6(1), 118-141. Doi: 10.25295/fsecon.991823

\begin{abstract}
biyoteknolojik tarımsal makinaların kazandırıması verimi artıracak, üretim fazlalığının oluşmasına yardımcı olacaktır. Zayıf yönler ve tehdit oluşturan faktörlerin etkisi minimuma indirildiği takdirde tarım sektöründe yeni politikaların ve inovasyon faaliyetlerinin hızlanması sağlanacaktır.
\end{abstract}

\title{
4. Sonuç
}

Üretmeyen bir neslin ortaya çıkması başka ülkelere olan bağımlılığı artırmaktadır. Türkiye'de son yıllara bakıldığında tarım sektöründe olumsuz bir gidişatın yaşanıldığı görülmektedir. Artan nüfusun gıda talebini karşılayabilmek ve küresel iklim değişikliğiyle mücadele edebilmek tarım sektörüne profesyonel bir yaklaşımla hareket edilmesini göstermektedir. Üretimde dışa bağımlıık, enerji fiyatlarının yükselmesi, şehirleşme oranının artması, ekilebilir tarım arazisinin yanlış kullanımı ve tarımsal istihdamın azalması gibi olumsuz faktörler tarım sektörü üzerinde bir baskı oluşturmaktadır. Bu baskı tarım ürünlerinin ithalata dayalı olarak temin edilmesine neden olmaktadır. Türkiye'de uygulanan tarım politikaları iç talebi karşılamakta yetersiz kalmaktadır. Kalkınma plânlarında stratejik bir yere sahip olan sektör artık bu konumdan çıkarılmıştır. Sektörün ulusal öncelikleri karşılaması için öncelikli sektörler arasına dahil edilmelidir. Dönemsel GSYiH rakamlarında tarım sektörünün büyüme hızında sürekli dalgalanmalar söz konusudur. Bu durum tarım politikalarının uygulanabilirlik konusunda sıkıntılar çektiğini göstermektedir. Üretmek ve dışa bağımlı ülke durumundan çıkmak hem çiftçilerin ekonomik sıkıntılarla karşılaşmasını hem de ülkenin dış ticarette açık vermesini engelleyecektir. Dolayısıyla bu durum Türkiye'nin tarım sektöründe politika değişimleri yapması gerektiğini göstermektedir. Tarımsal üretimde verim ve kalitenin yükselmesi için bu politikaların günümüz ekonomik şartlarına göre her yıl güncellenmesi gerekmektedir.

Bu çalışmada elde edilen sonuçlara göre; Türkiye tarımsal üretim alanında iyi bir performansa ve potansiyele sahiptir. Türkiye'nin iklim çeşitliliğine sahip olması ürün çeşitliliğini de beraberinde getirmektedir. Bu çeşitlilik artan nüfusun gıda talebini karşılamaktadır. İnsanların kaliteli, sağııklı ve güvenilir gıdaya ulaşması tarım sektörünün sorumluluğunu artırmaktadır. Bu doğrultuda devlet desteği ile tarım sektöründe girdi maliyetlerinin azaltılması, ar-ge destek ve yatırımların artırılması Türkiye'nin tarımsal üretimde iyi bir konuma gelinmesini sağlayacaktır. Tarımda verimlilik sağlandığı sürece Türkiye'nin tarım ürünleri ihracat oranları artacaktır. Türkiye'nin tarım sektöründe güçlü yönleri az olabilir fakat değişen yeni Dünya düzeni, artan talep ve sanayi sektöründe işlenen ürün sayısının artması bu sektörün önemini koruyacağı ve yeniliklere açık olacağını göstermektedir.

\section{Kaynakça}

Aktaş, E., Altıok, M., \& Songur, M. (2015). Farklı Ülkelerdeki Tarımsal Destekleme Politikalarının Tarımsal Üretim Üzerine Etkisinin Karşılaştırmalı Analizi. Anadolu Üniversitesi Sosyal Bilimler Dergisi, 15(4), 55-74.

Akyol, M., \& Soyyiğit, S. (2021). Tarımsal Verimliliğin Arttırılmasında Kamusal Ar-Ge Desteklerinin Etkisi: AB Üyesi Geçiş Ekonomileri Örneği. Türk Tarım ve Doğa Bilimleri Dergisi , 8(1), 30-42.

Alpagu, H. (2018). Karşılaştırmalı Bir Analizle Türkiye'de Tarım Politikası. Türkiye'de Tarım Politikaları ve Ülke Ekonomisine Katkıları, Atatürk Araştırma Merkezi Yayınları. Şanlıurfa, 37-51. 
Ekici, M. \& Tutar, F. (2022). Birincil Sektör Olarak Tarımın Dış Ticaretteki Stratejik Rolü.

Fiscaoeconomia, 6(1), 118-141. Doi: 10.25295/fsecon.991823

Aydın, B. (2009). Tarımsal Dış Ticarette Değişim. TMOB Ziraat Mühendisleri Odası, 1-111.

Aydın, M., \& Aydın, B. (2018). Gıda Rejimi Çerçevesinde Türkiye'nin Tarımsal Dış Ticareti Üzerine Bir Değerlendirme. Uluslararası Ekonomi, İşletme ve Politika Dergisi, 2(1) 111 130.

Bayramoğlu, Z. (2010). Tarımsal Verimlilik ve Önemi. Selçuk Üniversitesi Selçuk Tarım ve Gıda Bilimleri Dergisi, 24(3), 52-61.

Birişik, N. (2019). Küresel ve Ulusal Ölçekte Tarım ve Gıda Politikaları 'Gerçekler, Sorunlar ve Çözüm Önerileri'. DH Basın Yayın Matbaacılık, Ankara.

Çetin, R. (2020). Türkiye Tarım Ürünleri Bakımından Halâ Kendi Kendine Yeterli Mi ? Dış Ticaret Verileri Yoluyla Bir Analiz. Sakarya iktisat Dergisi, 9(2), 160-173.

Erçakar, M. E. (2007). Türk Tarımının Durumu ve Yabancı Sermaye Kullanımı 19.07.2021 tarihinde https://www.mevzuatdergisi.com/2007/08a/01.htm adresinden alındı.

Erçakar, M. E., \& Taşçı, H. M. (2011). Tarım Ürünlerinde Verimlilik-Fiyat illişkisi: Türkiye Üzerine Ampirik Bir Uygulama. Elektronik Sosyal Bilimler Dergisi, 10(36), 171-186.

Erkan, O. (2000). Türk Tarımında Uygulanan Politikalar. TMMOB Ziraat Mühendisleri Odası V.Teknik Kongre, Ankara, 22-76.

Görmüş, A. (2019). Türkiye'de Tarımsal İstihdamın Cinsiyete Dayalı Yapısı ve Sosyal Politika Önerileri. Eskişehir Osmangazi Üniversitesi IiBF Dergisi, 563-578.

Günaydın, G. (2009). Türkiye Tarım Politikalarında Yapısal Uyum:2000'li Yıllar. Küresel Kapitalizm Kıskacında Tarım, Gıda ve Köylülük Mülkiye Dergisi, 33(262), 175-221.

Güngül, M., \& Yenilmez, F. (2019). Üstel Düzleştirme Yöntemi İle Türkiye'nin Tarım Sektörü Dış Ticaret Dengesi Tahmini (2018-2023). Dokuz Eylül Üniversitesi Sosyal Bilimler Enstitüsü Dergisi, 959-980.

ітKіB. (2021). Hazırgiyim ve Konfeksiyon Sektörü 2021 Mart Aylık ihracat Bilgi Notu. ITKiB Genel Sekreterliği, Hazırgiyim ve Konfeksiyon AR-GE Şubesi.

Kalkınma Bakanlığı. (2018). On Birinci Kalkınma Plânı (2019-2023) Tarım ve Gıdada Rekabetçi Üretim Özel ihtisas Komisyonu Raporu. Ankara.

Larson, D. F., Martin, W., Şahin, Ş., \& Tsigas, M. (2014). Agricultural Policies and Trade Paths in Turkey. World Bank Group, 1-40.

Özkan, A. (2016). Türkiye Tarımında Yaşanan Sorunlar ve Alternatif Tarımsal Üretim Anlayışlarının Değerlendirilmesi. Balıkesir Üniversitesi Sosyal Bilimler Enstitüsü Dergisi, 411-430.

Resmi Gazete. (2021). 2021 Yılında Yapılacak Tarımsal Desteklemeler ve 2022 Yılında Uygulanacak Gübre ve Sertifikalı Tohum Kullanım Desteklerine İlişkin Karar. Karar Sayısı: 4760, Sayı: 31656, https://www.resmigazete.gov.tr/ adresinden 15.11.2021 tarihinde alındı.

Tarım ve Orman Bakanlığı. (2019). Tarım Politikaları Izleme ve Değerlendirme Raporu. https://www.tarimorman.gov.tr adresinden 30.07.2021 tarihinde alındı. 
Ekici, M. \& Tutar, F. (2022). Birincil Sektör Olarak Tarımın Dış Ticaretteki Stratejik Rolü.

Fiscaoeconomia, 6(1), 118-141. Doi: 10.25295/fsecon.991823

Tarım ve Orman Bakanlığı. (2021). https://www.tarimorman.gov.tr adresinden 10.07.2021 tarihinde alındı.

Taştanoğlu, E. (2018). 1980 Yılından Sonra Türkiye'de Uygulanan Tarımsal Politikalar ve Tarımın Ülke Ekonomisindeki Yeri. Niğde Ömer Halisdemir Üniversitesi Sosyal Bilimler Enstitüsü Yayınlanmış Yüksek Lisans Tezi.

TGDF. (2021). Türkiye Gıda ve İçecek Sanayii Dernekleri Federasyonu: https://www.tgdf.org.tr/gida-ve-tarim-sektorunde-dis-ticaret-2021e-nasil-basladi/ adresinden 25.07.2021 tarihinde alındı.

TGDF. (2021). 2020 Dış Ticaret Verileri. 26.07.2021 tarihinde https://www.tgdf.org.tr/wpcontent/uploads/2021/04/2020-Dis-Ticaret-Verileri-HD.pdf adresinden alındı.

TMO. (2021). 25.07.2021 tarihinde http://online.anyflip.com/vsmd/hshc/mobile/index.html adresinden alındı.

Tokatlıoğlu, M., vd. (2018). Küreselleşme Sürecinde Tarımın Stratejik Önemi ve Tarımsal Arz Güvenliğinin Sağlanmasında Devletin Rolü. Journal of Life Economıcs, 151-176.

TUik. (2020). 27.07.2021 tarihinde https://data.tuik.gov.tr/Kategori/GetKategori?p=disticaret-104\&dil=1 adresinden alındı.

TUiK. (2021). https://data.tuik.gov.tr/Kategori/GetKategori?p=tarim-111\&dil=1 adresinden 20.07.2021 tarihinde alınmıştır.

TUiK: https://www.tuik.gov.tr/ adresinden 15.11.2021 tarihinde alınmıştır.

Uzundumlu, A. S. (2012). Tarım Sektörünün Ülke Ekonomisindeki Yeri ve Önemi, Alınteri Zirai Bilimler Dergisi, 22(1), 34-44.

Yağcıoğlu, M. (2015). Tarımsal Büyüme ve Dış Ticaret Üzerine Makro Değerlendirmeler. İzmir Ticaret Borsası Ar-Ge Müdürlüğ̈̈, 1-11.

Yayar, R., \& Karkacıer, O. (2003). Tarım Sektörü Dış Ticaret Serileri İçin Model Belirleme ve Gelecek Tahmini (Box Jenkins Tahmin Yöntemi). GOU Ziraat Fakültesi Dergisi, 20(2), 89-108.

Etik Beyanı: Bu çalışmanın tüm hazırlanma süreçlerinde etik kurallara uyulmuştur. Aksi bir durumun tespiti halinde Fiscaoeconomia Dergisinin hiçbir sorumluluğu olmayıp, tüm sorumluluk çalışmanın yazarlarına aittir.

Yazar Katkıları: Merve EKici, çalışmanın tüm bölümlerinde özellikle de çalışmanın giriş, sonuç ve ampirik literatür bölümlerinin oluşması aşamalarında katkı sağlamıştır. Filiz TUTAR, çalışmanın tüm bölümlerinde özellikle de revizyon ve kontrol aşamalarında katkı sağlamıştır. Çalışmada 1. yazarın katkı oranı \%50 ve 2. yazarın katkı oranı \%50'dir.

Çıkar Beyanı: Yazarlar arasında çıkar çatışması yoktur.

Teşekkür: Yayın sürecinde katkısı olan hakemlere ve editör kuruluna teşekkür ederiz. 
Ekici, M. \& Tutar, F. (2022). Birincil Sektör Olarak Tarımın Dış Ticaretteki Stratejik Rolü.

Fiscaoeconomia, 6(1), 118-141. Doi: 10.25295/fsecon.991823

Ethics Statement: Ethical rules were followed in all preparation processes of this study. In case of detection of a contrary situation, Fiscaoeconomia has no responsibility and all responsibility belongs to the authors of the study.

Author Contributions: Merve EKICI, has contributed to all parts of the study, especially in the stages of the introduction, conclusion and ampiric literatüre. Filiz TUTAR, has contributed to all parts of the study especially in the revision and control stages. 1st author's contribution rate: $\% 50,2$ nd author's contribution rate: $\% 50$.

Conflict of Interest: There is no conflict of interest between the authors.

Acknowledgement: We thank the referees and editorial board who contributed to the publishing process. 
Ekici, M. \& Tutar, F. (2022). Birincil Sektör Olarak Tarımın Dış Ticaretteki Stratejik Rolü.

Fiscaoeconomia, 6(1), 118-141. Doi: 10.25295/fsecon.991823

\section{Agriculture's Strategic Role in Foreign Trade as a Primary Sector}

\section{Merve EKICi \& Filiz TUTAR}

\section{Extended Abstract}

Agriculture is an activity that has existed since the first settled life of humankind. This activity has the quality of being a source of life for generations. As the world order changed, countries started to group according to some of their characteristics and to do agriculture with more professional machinery and equipment. Considering the developed countries, it can be said that the productivity of agricultural activities is essential. Accordingly, Turkey was a selfsufficient country in terms of agricultural raw materials before 2000. However, this position showed a change after 2000 and became a foreign-dependent situation for raw materials. This situation led to the formation of foreign trade deficits. In order to prevent this bad condition, Turkey has made some changes in its agricultural policies. Thanks to the agricultural support policies, the foreign dependency ratio was tried to be reduced by providing the necessary financial support to the factors that increase the productivity and quality in agriculture, such as irrigation, local seeds, and the use of machinery. In this direction, the Agricultural Reform Implementation Project was implemented in 2002. This project is not only to meet the domestic markets' various agricultural products needs but also aims to have a comparative advantage. This objective increased the export figures and enabled the elimination of a possible imbalance in the foreign trade volume. The necessity of production in order to achieve economic growth was emphasized in this project.

Factors such as the protection of natural resources, a cleaner world, and the preservation of the quality of life have enabled Turkey to establish different systems in agricultural production. In this context, Good Agricultural Practices (GAP) and organic farming systems have been started to be implemented. These two systems ensured high quality, efficient and healthy production. These two systems, which were put into practice in certain cities, have now been put into practice in more regions of Turkey. These two systems, which also contribute to the improvement of the living standards of the farmers, didn't take long for them to take their place in the development plans. In the agricultural sector, which is directly related to climatic conditions, an increasing or decreasing course of production yield should cease to be an inevitable situation. Because the farmers loss of income and make loss is the reason for leaving the profession. In order to prevent this, the farmers should be made aware. The existence of opportunities such as concessional loans, insurance, input subsidies increases the sustainability of the profession. Encouraging farming shows that the country encourages production, not consumption. When we look at developed countries, it is seen that the agricultural sector has a small share in employment. However, the fact that they have a mindset that cares about production efficiency also shows how much agricultural support works by reducing foreign dependency on raw materials. The adoption of a capital-intensive production approach, not labor-intensive production in the sector, brings efficiency and quality in production. Agricultural production should be emphasized for the development and industrialization of Turkey. Although the share of the sector in national income is low, providing input to other sectors makes agricultural production important. The fact that it is a source for industrial areas such as textile, leather, food, clothing, and tobacco proves the closeness of its relationship with economic areas. Agricultural activities, which are compatible 
Ekici, M. \& Tutar, F. (2022). Birincil Sektör Olarak Tarımın Dış Ticaretteki Stratejik Rolü.

Fiscaoeconomia, 6(1), 118-141. Doi: 10.25295/fsecon.991823

with many other sectors such as logistics, wholesalers, hotels, restaurants, and retailers are a decisive sector of the country's economy.

When Turkey's 2020 foreign trade data is examined, the agriculture, food, and beverage sector realized 20.7 billion dollars of exports and 16.1 billion dollars of imports. The foreign trade balance is 4.64 billion dollars. Turkey exports to 207 countries in total. The most exported countries are; Iraq is 2.9 billion dollars, Germany is 1.6 billion dollars, Russia is 1.4 billion dollars, the USA is 1.1 billion dollars and Italy is 0.8 billion dollars. Exports to these countries represent $38 \%$ of total exports. It also imports from 173 countries. The top five importing countries are; Russia is 3.2 billion dollars, Brazil is 1.4 billion dollars, Ukraine is 1 billion dollars, the USA is 0.9 billion dollars and Malaysia is 0.6 billion dollars. Imports from these countries constitute $44.6 \%$ of total imports. In the first month of 2021 , the agriculture, food, and beverage sector exported 1.63 billion dollars and imported 1.39 billion dollars. In January 2021 , the foreign trade balance of the agricultural sector decreased by $38.4 \%$ compared to the same period of the previous year. The export of value-added products in foreign trade provides a plus for the economy. In January 2021, the most exported value-added products in foreign trade are respectively; hazelnut kernels are 127.7 million dollars, flour 85.2 million dollars, and mandarin orange 57.1 million dollars. These products constituted $16.6 \%$ of total exports. In the same period, the most imported agricultural products are; wheat is 188.8 million dollars, soybeans are 102.3 million dollars and sunflower oil is 58 million dollars. These figures show that Turkey has a good potential in agricultural production.

In this study, the importance of the agricultural sector, which is the backbone of Turkey's foreign trade, and the agricultural policies applied are mentioned. In the study results; It has been concluded that the income imbalance of farmers should be ended, productivity and sustainability should be taken as a basis, farming should not be abandoned, it should be stimulated and encouraged, and agriculture is not an inward-looking sector that only concerns itself. 